\title{
Strategies to strengthening the creative economy in economic recovery during the covid 19 pandemic in the coastal society in Kema District, Minahasa Utara Regency
}

Lyndon Reindhart Jacob Pangemanan ${ }^{1}$, Sherly Gladys Jocom ${ }^{2}$, Novie Pankie Lukas Pangemanan ${ }^{3} *$

a lyndonpangemanan07@gmail.com

${ }^{a}$ Agribusiness Study Program Lecturer, Faculty of Agriculture, Universitas Sam Ratulangi, Manado

\begin{abstract}
This study aims to study the potential of marine resources and coastal zones in the Kema District. The research was carried out for 8 months, starting from March to October 2021, with the research location in the Kema District. This research was designed descriptively, with a survey method. Sampling was done intentionally (purposive sampling) on research informants with the number of respondents being 20 informants. The data collected in this study are primary and secondary data. Primary data were collected directly through indepth interviews with informants. The results showed that the policy strategy for strengthening the creative economy of the coastal community of Kema District was carried out as soon as possible ten (10) priority scale activities with political, economic, social/cultural considerations, security and security and security, ecology, legal institutions, technology and infrastructure.
\end{abstract}

Keywords: Strengthening Strategy; Creative Economy; Covid-19 pandemic; Coastal. 


\section{Introduction}

\section{Background Research}

Economic development of coastal communities in Kema Subdistrict located in the East coast of North Minahasa Regency should be carried out as a process of continuous social and cultural change, so as to strengthen the economic resilience of local communities based on resources resulting from the sea and coastal zones. The characteristics of social groups (communities) are influenced by the environmental conditions in which they live. Indonesia itself has a very varied society depending on environmental conditions and local traditions. Indonesia is also one of the countries with the longest coastline in the world. Residents who live in coastal areas commonly known as coastal communities, have special characteristics that distinguish them from communities elsewhere.

Indonesia since March 2020 was hit by the Covid 19 disaster, where the first confirmed case of coronavirus infection that causes Covid-19 in Depok City since then the government conducted activities to prevent the spread of the corona virus that did not damage various sectors of life and economy. Covid-19 has exacerbated economic disparities in society that existed before the outbreak. Previously having a vulnerable life and work is increasingly uncertain livelihood since the outbreak of Covid-19.

Strategies to strengthen the creative economy of coastal communities of Kema Subdistrict can increase the income of coastal communities, so that various potential marine economic commodities such as various types of fish that can be processed into jerky, abon, crackers, meatballs, salted fish, anchoics, and ebi shrimp, fish and seaweed cultivation and other commodities relatively contribute significant economic value to marine resources commodities and coastal zone resources, In the current situansi the community is struggling during the covid 19 pandemic.

Dahuri et al. (2004) stated that, the integrated management of coastal and marine areas is an approach to managing coastal areas involving two or more ecosystems, resources, and integrated development activities to achieving sustainable coastal development. In this context, integration (integration) is contained in three dimensions: sectoral, scientific, and ecological relatedness. Sectorally integrated integration means that there needs to be coordination of duties, authorities and responsibilities between sectors or government agencies at a certain government level (horizontal integration); and between levels of government from the village, subdistrict, district, province, to the central level (vertical integration). The integration of scientific viewpoints requires that in the management of coastal areas should be implemented on the basis of interdisciplinary approaches, involving the relevant fields of economics, ecology, engineering, sociology, law and others.

Clark (1996) stated that integrated management of coastal areas is a planning activity to manage coastal resources through participation or involvement by economic sectors, government agencies, and nongovernmental institutions that have links to the management of the coastal area.

The policy of empowerment and economic strengthening of coastal communities is carried out so that poor and vulnerable groups affected by the covid 19 pandemic can be productive and develop. So that it can soon be economically independent. The hope is that it can move and spur the community to survive and simultaneously increase income even though the Covid 19 pandemic is there.

Some explanations, researchers interested in researching the potential of marine resources and coastal zones of Kema Subdistrict then seek to develop the potential of the community in the utilization and processing of marine resources and coastal zone resources in addition to conventional activities are also empowered to strengthen creative economic efforts. Researchers seek to elaborate on the strength and opportunity to obtain creative economy strengthening strategies that are appropriate in the circumstances of local communities in order to recover the economy of the community during the Covid 19 pandemic. The object of this research is 
the coastal community of Kema Subdistrict through community efforts in the utilization of marine resources based on the creative economy.

\section{1-2 Background Issues}

Based on background, the problem that is the focus of this research is: How is the strategy to strengthen the creative economy during the Covid 19 pandemic based on the potential of marine resources and coastal zones in the coastal communities of North Minahasa District Kema District?

\section{1-3 Benefits of Research}

a. For Researcher

This research is expected to provide input, add insight, and can be a contribution of thought in relation to increasing the role of coastal communities for strengthening the creative economy in utilizing the marine resources of existing coastal zone resources with the capabilities they have. For the next time, this research can be used as a reference material in responding to similar things.

b. For Society

This research can provide an overview and provision of the public in general about strategies in developing skills to cultivate creative economies based on marine resources and coastal zones with the aim to create added product value so that there is an increase in income despite facing difficult situations such as the current situation of the Covid 19 pandemic disaster.

c. For Knowledge

This research is expected to be used as a reference material for future studies related to community strategies in strengthening and processing the creative economy based on marine resources and coastal resources in increasing income through added value due to creative economic activities.

\section{1-4 Research Purpose}

This research aims to reveal and find creative economic development strategies based on the assessment of creative economic problems during the covid 19 pandemic in coastal areas in Kema District of Minahasa Regency.

\section{Literature and theoretical foundations of research}

Based on the formulation of the problems that have been described in the previous chapter, the following is stated the formulation of the library about the dimensions.

\section{2-1 Coastal Communities}

The definition of coastal areas is carried out on three approaches, namely ecological approach, administrative approach, and planning approach. According to Suprihayono (2007: 14) the coastal area is the area of meeting between land and sea to land coastal areas covering the land, both dry and submerged, which are still influenced by marine properties such as tides, sea breezes, and saltwater seepage. Sunanik (2013) explained that the sustainability of the livelihoods of poor households in coastal areas needs to be sought for sustainable creative economic opportunities without damaging the surrounding natural resources. 


\section{2-2 Covid-19 Pandemic}

According to Rothan HA and Byrareddy (2019) cases of pneumonia were first reported in Wuhan, Hubei Province. Initially the disease was named as 2019 novel coronavirus (2019-nCoV), then WHO announced a new name on February 11, 2020 namely Coronavirus Disease (COVID-19) caused by severe acute respiratory syndrome coronavirus-2 (SARS-CoV-2) (WHO, 2020) March 12, 2020, WHO announced COVID-19 as a pandemic.

\section{2-3 Creative Economics}

Gemiharto et al. (2009) stated that the term creative economy was first introduced by a character named John Howkins, author of the book "creative economy: how people make money from ideas" (2001).

The creative economy has a very strategic role in economic development and business development. The implementation of the concept of creative economy to the form of creative industry development is a smart solution in maintaining the sustainability of economic development and business development in the era of global competition. (Moelyono Mauled, 2010).

The development of science, information technology and innovation led to changes in production systems, in recent years, knowledge, creativity and innovation have become the cogs of many countries' economies. Innovation is a better or more effective creation of products, processes, services, technologies, or ideas that are already available for market, government, and community purposes.

\section{2-4 Concept of Strengthening Strategy}

Kotler (2005) states that: "A strategy is a set of ways to achieve a goal, and a strategy is a logical approach that will determine the direction of an action. Theoretically, there are four types of strategies used, associated with circumstances and needs. Classical Strategy and Sitemic Strategy are used under normal circumstances whereas evolutionary strategies and process strategies are used to address crisis situations. Evolutionary and classical strategies can be used to achieve maximum profit and instead systematic process and strategic strategies are to realize optimum profits.

In its implementation, the strategy is divided into four categories, namely leadership strategy (leadership strategy) and strategy choices (strategy choices) and growth strategy (growth strategy) and management strategy (managing strategy). The choice of strategy must be used with a place so that the resources used in the strategy can achieve their goals and objectives because. There are strategies that are structured for the short and medium and long term.

\section{Research Methodology}

\section{3-1 Time and Place of Research}

This study was conducted for 8 months, from March to October 2021, with a research location in Kema Village Regency.

\section{3-2 Research Method}

This research is designed descriptively, with survey methods. Sampling (respondents) was carried out purposively to informants, namely Camat, Village Head, Head of Tourism Office, Head of Social Service and PMD, Community of Creative Economic Actors. The number of responses was 20 informants. The data collected in this study includes primary and secondary data collected 
directly with survey techniques through in-depth interviews (in-interview) with informants. These data include the age, level of education, housing characteristics, home ownership status, income and expenditure of farmers. Secondary data in the form of geographical conditions, socio-economic and cultural conditions of the community. In data collection methods used is a survey method through in-person interviews guided by a list of questions (questionnaires) that have been designed and prepared.

\section{3-4 Data collection method}

Data collection techniques as follows: 1. Library research Collection is done by reading literature related to books / articles, documents that have relevance to the topics discussed in this study. 2. Observation, which is the collection of data by direct observation and through internet browsing 3. Interview, which is a data collection technique where researchers directly hold q\&A with informants using interview guidelines recording or video tools. 4. Online data search; Data collected is like a literature study but the thing that distinguishes only the media where data and information is taken by utilizing online data over the internet.

\section{3-4 Data Analysis Methods}

To get objective results in this study, the data obtained in the field will be analyzed qualitatively this is based on the development that this research is expressed in the form of question questions, responses, and interpretations obtained from observations, interviews and literature studies, to clarify the picture of research results.

\section{Results and Discussion}

\section{4-1 General Description of the Research taken place}

Kema Subdistrict is a subdistrict in North Minahasa Regency, North Sulawesi, Indonesia. Territorial boundaries: The North borders Kauditan District, Bitung City; The South borders Minahasa Regency; The West side borders kauditan subdistrict; East borders the Maluku Sea.

Kema District is one of the subdistricts located in North Minahasa Regency, its capital in Kema Satu Village, and has an area of $120.96 \mathrm{~km} 2$. Kema District consists of 10 villages, namely Makalisung, Waleo, Lilang, Lansot, Kema Tiga, Kema Dua, Kema Satu, Tontalete, Tontalete Rok-Rok, and Waleo Dua (BPS Minut. 2018).

The area of Kema Subdistrict changed from $133.87 \mathrm{~km} 2$ to $120.96 \mathrm{~km} 2$ in 2013 due to changes in the boundaries of Tontalete Rok-Rok village, which borders Bitung City, and the completion of the calculation of waleo and Waleo Dua village area.

The village with the largest area is Waleo Village, which is an area of $\pm 25.57 \mathrm{~km} 2$, while the village with the smallest area is Kema Tiga Village, covering an area of $\pm 0.90 \mathrm{~km} 2$. Kema subdistrict is located at an altitude of \pm 1 meter above sea level.

Judging from the location of the village, there are four villages located on the slopes, one village in the valley, and five villages on the expanse. Of the ten villages in Kema Subdistrict, eight villages are directly adjacent to the sea / coastal villages, and two villages do not directly adjacent to the sea / villages are not coastal. (Source: Kema Subdistrict in Numbers 2020). 


\section{4-2 The State of the Population}

Population

The population in Kema District amounted to 16,272 people in 2020, with KK 3,684 KK spread across 10 villages.

Table 1 . Population by Gender in 2020

\begin{tabular}{cccc}
\hline No & Gender & Population & Percentage (\%) \\
\hline 1 & Men & 8.163 & 51 \\
2 & Women & 8.109 & 49 \\
\hline Total & $\mathbf{2 0 2 0}$ & $\mathbf{1 6 . 2 7 2}$ & $\mathbf{1 0 0}$
\end{tabular}

(Resourced : Kantor Kecamatan Kema, 2020)

Table 1 shows that the number of population data in 2020 based on male sex amounted to 8,163 people with a percentage of $51 \%$ greater than the population with a female gender of 8,109 people with a percentage of $49 \%$.

table:

The number of residents by livelihood in Kema Subdistrict can be seen in the following

Table 2. . Population by Livelihood

\begin{tabular}{llll}
\hline No & Livelihood & Population & $\begin{array}{l}\text { Percentaage } \\
(\%)\end{array}$ \\
\hline 1 & Farmers & 1706 & 46,48 \\
2 & Fisherman & 1120 & 30,51 \\
3 & Entrepreneur & 397 & 10,81 \\
4 & PNS & 146 & 3,98 \\
5 & TNI/Polri & 8 & 0,22 \\
6 & Private Employees & 294 & 8,00 \\
\hline & Total & $\mathbf{3 6 7 1}$ & $\mathbf{1 0 0}$
\end{tabular}

(Resourced : Pemerintah Desa)

Table 2 shows that most of the population in Kema District has farmers' livelihoods with a total of 1,706 people or $46.48 \%$. This is because Kema District is one of the sub-districts whose 
residents are many engaged in the agricultural sector, in addition, the population also moves a lot of the fishery sector, because the villages are located on the beach.

\section{4-3 Respondent Characteristics}

In this study, respondents were creative economy actors (MSMEs) who have businesses such as culinary, fashion, and service businesses.

Characteristics of these respondents are to find out the diversity that exists in respondents based on gender, age, and business fields carried out. This is expected to provide a fairly clear picture of the condition of the respondent and its relation to the problem and purpose of the study.

Age

Table 3. . Population by Age

$\begin{array}{lll}\text { Age (year) } & \text { Respondent } & \text { Percentage (\%) }\end{array}$

\begin{tabular}{lcc}
$15-30$ & 9 & $45.00 \%$ \\
$31-45$ & 6 & $30.00 \%$ \\
$46-60$ & 5 & $25.00 \%$ \\
\hline Total & $\mathbf{2 0}$ & $\mathbf{1 0 0 \%}$
\end{tabular}

(Resourced : Data processed Data Primer, Tahun 2021)

From table 3 it can be known that the most respondents are respondents with ages 15-30, namely 9 respondents with a percentage of $45.00 \%$ and the lowest is respondents with ages 46-60 which is 5 respondents with a percentage of $25.00 \%$.

Gender

Table 4 shows that most respondents are women, with 11 respondents with a percentage of $55.00 \%$, and men as many as 9 respondents with a percentage of $45.00 \%$. This shows that the gender of respondents is dominated by women.

Respondents' criteria by gender are displayed in the following table:

Table 4. Respondents by Gender

$\begin{array}{lll}\text { Gender } & \text { Respondent } & \text { Percentage (\%) }\end{array}$


(Resourced : Processed by Data Primer, Tahun 2021)

Level of Education

Table 5. Respondents Based on Education Leve

\begin{tabular}{ccc}
\hline Education & Respondent & Percentage (\%) \\
\hline Elementary & - & - \\
Junior High & 2 & $10.00 \%$ \\
Senior High & 11 & $55.00 \%$ \\
Bachelor & 7 & $35.00 \%$ \\
\hline Total & $\mathbf{2 0}$ & $\mathbf{1 0 0 \%}$ \\
\hline
\end{tabular}

(Resourced : Diolah dari Data Primer, Tahun 2021)

Table 5 shows that the education level of respondents who completed junior high school education amounted to 2 respondents with a percentage of $10.00 \%$, high school amounted to 11 respondents with a percentage of $55.00 \%$, and college amounted to 7 respondents with a percentage of $35.00 \%$.

Business Field

Table 6. Respondents Based on Business Field

\begin{tabular}{ccc}
\hline Types of Industrial Subsectors & Respondent & Percentagee (\%) \\
\hline Fashion & 4 & $20.00 \%$ \\
Culinary & 13 & $65.00 \%$ \\
Service & 3 & $15.00 \%$ \\
\hline
\end{tabular}


(Resourced : Processed from Data Primer, Tahun 2021)

Table 6 shows that the field of fashion business as much as 4 with a percentage of $20.00 \%$, culinary business field as much as 13 with a percentage of $65.00 \%$, and service business field as much as 3 . This shows that in kema subdistrict is more dominant with the culinary business field.

\section{Discussion and Conclussion \\ 5-1 Policy Analysis of Creative Economy Strengthening Strategies}

Location):

The Study of The Problem of a Problem Introduction to Problems in Lokus (Special

The results of interviews with 20 respondents to the creative economy business (name attached), by way of open questions (meaning digging all unek and information). Data retrieval technique through "in depth interview". After conducting a survey on respondents obtained in a found problem of the business level of the creative economy.

\section{Situation of Creative Economy Business Problems in Coastal Areas of Kema Subdistrict.}

The level of creative economy business in the coastal region of Kema Subdistrict tends to decrease. In this situation, it is suspected that meta problems arise due to the situation of the covid 19 pandemic, where there is a Restriction on the Movement of Community Activities (PPKM).

\section{Meta problems:}

a. The movement of people is restricted, roads / access to business premises installed portals

b. Lack of information about the status / level affected by covid in the destination of creative economy business.

c. Slow direct assistance to business actors.

d. Lack of coordination between creative economy business actors and local governments.

e. Lack of creative economy business capital capabilities.

f. Lack of ability of business actors to predict the development of the situation

g. Business management skills are limited.

h. Informatics technology mastery skills / digitization is still low.

i. Lack of information access to financial institutions, such as Banks, Cooperatives and Bumdes.

j. Lack of creative skills

$\mathrm{k}$. The place of business is not yet viable (depending on the weather situation)

Eleven (11) meta problem points need to be surveyed to 20 respondents as a sample to get substantive problems, then made a questionnaire to respondents with statistical frequency distribution methods / techniques.

Scoring is in accordance with the need to increase the level of creative economy effort what problems are urgently resolved as soon as possible.

Score: 100, meaning the problem is very urgent; 75 means an urgent question; 50 means less urgent questions; $\mathrm{n}=20$. 
Table 7. Meta Problem Results

\begin{tabular}{|l|l|l|l|l|}
\hline No. & \multicolumn{1}{|c|}{ Meta Problem } & $\begin{array}{l}\text { Value } \\
(\mathrm{n}=20)\end{array}$ & $\begin{array}{l}\text { Weight } \\
(\%)\end{array}$ & $\begin{array}{l}\text { Priority } \\
\text { List }\end{array}$ \\
\hline 1 & $\begin{array}{l}\text { The movement of people is restricted, roads / access to business premises } \\
\text { installed portals }\end{array}$ & 1750 & 60 & 3 \\
\hline 2 & $\begin{array}{l}\text { Lack of information about the status / level affected by covid in the } \\
\text { destination of creative economy business. }\end{array}$ & 1525 & 35 & 6 \\
\hline 3 & $\begin{array}{l}\text { Slow direct assistance to business people. } \\
\text { Lack of coordination between creative economy businesses and local } \\
\text { governments. }\end{array}$ & 1800 & 60 & 1 \\
\hline 5 & Lack of creative economy business capital capabilities. & 1700 & 50 & 4 \\
\hline 6 & Lack of ability of business actors to predict the development of the situation & 1450 & 30 & 9 \\
\hline 7 & Business management skills are limited. & 1475 & 25 & 8 \\
\hline 8 & Informatics technology mastery skills / digitization is still low. & 1775 & 60 & 2 \\
\hline 9 & $\begin{array}{l}\text { Lack of information access to financial institutions, such as Banks, } \\
\text { Cooperatives and Bumdes }\end{array}$ & 1525 & 30 & 7 \\
\hline 10 & Lack of creativity skills. & 1550 & 35 & 5 \\
\hline 11 & The place of business is not yet viable (depending on the weather situation). & 1425 & 20 & 11 \\
\hline
\end{tabular}

Resourced : Data processed

Information :

"Value" is the sum value of the score obtained from the survey results of 20 samples

"Weight" is the frequency distribution of a very urgent problem to be resolved as soon as possible against the number of 20 samples.

"Priority Order" is a meta-priority order of problems, i.e. the order of priorities that are getting smaller means that a problem is urgent to be solved and vice versa.

\section{Problem Definition:}

Obtained by grouping problems from meta problems and according to problem groups. From the meta problem is done the definition of the problem based on:

- $\quad$ Socio-Cultural Issues ; point : j, g.

- $\quad$ Economic Issues ; point : e, $\mathrm{f}, \mathrm{h}, \mathrm{k}$

- Institutional, legal, political issue: a, b, c, d.i.

Substantive Issues:

Obtained from the results of the survey with the approach of frequency distribution weighting methods so that problems are obtained substantive / fundamental problems (as soon as possible resolved through policy strategies). It is as follows:

a. The movement of people is restricted, roads / access to business premises installed portals

b. Lack of information about the status / level affected by covid in the destination of creative economy business.

c. Slow direct assistance to business actors

e. Lack of creative economy business capital capabilities.

g. Business management skills are limited 
h. Informatics technology mastery skills / digitization is still low.

i. Lack of information access to financial institutions, such as Banks, Cooperatives and Bumdes.

j. Lack of creativity skills.

(Issues $\mathrm{d}, \mathrm{f}, \mathrm{k}$, are eliminated based on assessment and weighting of attachments)

Formal Issues.

Issues that are officially immediately taken action through policy strategies based on legislation and regulations and budget capabilities. The results of the survey in 20 samples of creative economy actors obtained four (4) problems as formal problems as follows:

a. The movement of people is restricted, roads / access to business premises installed portals

c. Slow direct assistance to business actors.

e. Lack of creative economy business capital capabilities.

h. Informatics technology mastery skills / digitization is still low.

\section{Goal Setting}

Based on the formal problems set, it is necessary to formulate the goal to overcome the problem of decreasing the creative economy business, through a policy strategy to address four (4) problems in formal problems, the goal is to strengthen the creative economic efforts of the people of coastal areas of Kema Subdistrict. The objectives for strengthening creative economy efforts during the Covid 19 pandemic are:

1. Increase public awareness about health protocols and need to be vaccinated in order to be loosened the problem of restricted community movement, roads / access to business places installed portals.

2. Revitalize and strengthen in accordance with the applicable rules of social assistance and business assistance agencies to the community. To overcome the slowness of direct assistance to business actors.

3. Increase the Capacity of Creative Economy Business to strengthen business capital.

4. Improve the mastery skills of informatics technology / digitization to anticipate business in the covid 19 pandemic.

Determination of Alternative Strategies for Strengthening the Creative Economy during the Covid 19 pandemic

After determining the problems and objectives to be achieved in order to be fulfilled strengthening creative economic efforts such as; keep trying in the time of pandemic covid 19, the guarantee of business capital, business assistance in the time of the current covid 19 pandemic, and increased mastery of informatics technology for businesses in the covid 19 pandemic for the community of creative economy entrepreneurs of kema sub-district coastal areas, the following policy alternatives are set:

1. Enforce strict rules and unfailing socialization, persuasive about the importance of carrying out health protocols and injecting vaccines for those who do not suffer from certain diseases.

2. Encourage local governments to be smarter to read / observe the situation of the development of PPKM levels that occur on a micro scale or local area, because this is very related to the policy of movement of community activities, do not be beaten flat, because the inaccuracy of the local government to observe the development of PPKM levels the impact on community movements 
on micro-business access will be limited.

3. Portal barriers are sought not closed completely, but for people who have standardized health protocols / evidence has been vaccinated is given the opportunity to access to the creative economy business premises.

4. Strict monitoring of the distribution of social assistance and business assistance is carried out by institutions that are authorized in structural tiers, direct supervision on the ground by structural officials and involve Social Community Institutions (LSM) to conduct monitoring and evaluation.

5. Update the recipient's data in a transparent and accountable manner, tiered from the village level to the level of business assistance

6. Improving symmetrical information from the government and banks as a distributor of business assistance in online applications and manually off-line, so that synchronous and fast information is obtained by the recipient

7. Conducting empowerment activities through business management training activities, improving creative economy business skills, business assistance and business capital assistance, so that the problem of lack of creative economy business capital capabilities can be resolved and business sustainability.

8. Conducting training to increase the capacity of creative economy efforts by the relevant government and the government through APBDesa, Resourced Village Fund.

9. Conducting Community Partnership Program (PKM), through business management training activities, creative economy business development, resourced capacity building of entrepreneurial human power, mentoring sustainable experts and sustainability.

10. Conducting practical informatics technology mastery training, such as online marketing using applications, social media, "market place" and digitalization of creative economy businesses.

Formulation of Policy Alternatives According to Priority Scale:

I. a. Conducting close supervision by institutions channeling social assistance and business assistance is carried out in structural tiers, direct supervision on the ground by structural officials and involves Community Social Institutions (LSM) to conduct monitoring and evaluation,

b. Conducting close supervision by institutions channeling social assistance and business assistance is carried out in structural tiers, direct supervision on the ground by structural officials and involves Community Social Institutions (LSM) to conduct monitoring and evaluation,

c. Update the recipient's data in a transparent and accountable manner, tiered from the village level to the level of business assistance.

d. Improving symmetric information from the government and banks as a distributor of business assistance in online applications and manually off-line, so that synchronous and fast information is obtained by the recipient.

e. Restoring functions and tupoksi in accordance with the applicable rules of the competent agency as a distributor of social assistance and MSME assistance with strict supervision, involving LSM, so that the distribution is on target, on time and on allotment so that it can be built and 
strengthen creative economic efforts in the covid 19 pandemic.

II. a. Enforce strict rules and unfailing socialization, persuasive about the importance of carrying out health protocols and injecting vaccines for those who do not suffer from certain diseases

b. Encourage local governments to be more intelligent to read / observe the situation of the development of PPKM levels that occur on a micro scale or local area, because this is very related to the policy of movement of community activities, do not be beaten flat, because the inaccuracy of local governments observing the development of PPKM levels the impact on community movements on micro-business access will be limited.

c. Efforts to prevent the portal is not closed completely, but for people who have standardized health protocols / evidence has been vaccinated given the opportunity to access to the place of business.

d. Increasing public awareness about health protocols and needing vaccines in order to be loosened the problem of restricted community movement, roads / access to business premises installed portals. subdistrict.

e. Strengthening / Returning to normal creative economic efforts of coastal areas of Kema

III. a. Conducting practical informatics technology mastery training, such as online marketing using applications, social media, "market place" and digitalization of creative economy businesses.

Conducting practical informatics technology mastery training, such as online marketing using applications, social media, "market place" and digitalization of creative economy businesses.

b. Improve the mastery of informatics technology / digitalization to anticipate business in the covid 19 pandemic.

c. Build the skills of creative economy entrepreneurs who are more master of technology, including digital-based technology.

IV. a. Conducting empowerment activities through business management training activities, improving creative economy business skills, business assistance and business capital assistance, so that the problem of lack of creative economy business capital capabilities can be resolved and business sustainability.

b. Conducting training to increase the capacity of creative economy efforts by the relevant government and the government through APBDesa, Resourced Village Fund.

c. Conducting Community Partnership Program (PKM), through training activities business management of creative economy business development, resourced capacity building of entrepreneurial human power, mentoring of sustainable experts and sustainability.

d. Community (PKM), through training activities - business management of creative economy business development, resourced capacity building of entrepreneurial humanpower, 
mentoring of sustainable experts and sustainability.

e. Increasing the Capacity of Creative Economy Business to strengthen business capital in the covid 19 pandemic; Building manjerial skills as a creative economy entrepreneur, increasing business efficiently and effectively sustainably and continuing: and Formed a strong and independent entrepreneurial human.

\section{5-2 Recommendations of Policy Strategy to Strengthen the Creative Economy of Coastal Communities of Kema Subdistrict in the Pandemic Period Covid 19.}

1. Carrying out close supervision by institutions Channeling social assistance and business assistance are carried out in structural tiers, direct supervision on the ground by structural officials and involving Community Social Institutions (LSM) to conduct monitoring and evaluation.

2. Update the recipient's data transparently and akunTable, tiered from the village level to the level of business assistance.

3. Improving symmetric information from the government and banks as a distributor of business assistance in online applications and manually off-line, so that synchronous and fast information is obtained by the recipient.

4. Enforce strict rules and unfailing socialization, persuasive about the importance of carrying out health protocols and injecting vaccines for those who do not suffer from certain diseases.

5. Encouraging local governments to be more intelligent to read / observe the situation of the development of PPKM levels that occur on a micro scale or local area, because this is very related to the policy of movement of community activities, do not be beaten flat, because the inaccuracy of the local government to pay attention to the development of PPKM levels the impact on community movements on micro-business access will be limited.

6. Efforts to prevent the portal is not closed completely, but for people who have standardized health protocols / evidence has been vaccinated given the opportunity to access to the place of business.

7. Conducting practical informatics technology mastery training, such as online marketing using applications, social media, "market place" and digitalization of creative economy businesses.

8. Conducting empowerment activities through business management training activities, improving creative economy business skills, business assistance and business capital assistance, so that the problem of lack of creative economy business capital capabilities can be resolved and business sustainability..

9. Conducting training to increase the capacity of creative economy efforts by the relevant government and the government through APBDesa, Resourced Village Fund.

10. Conducting Community Partnership Program (PKM), through training activities - business management of creative economy business development, resourced capacity building of entrepreneurial human power, mentoring of sustainable experts and sustainability. 


\section{BIBLIOGRAPHY}

Ruzz,)

Barnawi, Mohammad.2012. Arifin, Ethics and Education Profession, (Yogyakarta: Ar-

Dahuri, R., Rais, J.M., Ginting S.P. and Sitepu, M.J., (2004). Integrated Management of Coastal and Marine Area Resources. Third Print, Revised Edition. PT Pradnya Paramita, Jakarta.

Kotler, Philip. 2005. Marketing Management, Volumes 1 and 2. Jakarta: PT. Gramedia Group Index.

Academic Manuscript of Coastal Area Management, 2000. Department of Marine Affairs and Fisheries of the Republic of Indonesia, Jakarta.

Mauled, Moelyono. 2010. Moving the Creative Economy Between Demands and Needs. Jakarta: Rajawali Pers.

Paruntu.C.P and A.P.Rumengan., (2018). Practical Guide to Marine and Fisheries Policy Analysis. Unsrat Press, Manado.

Robert C. Bogdan, transleter Alih bahasa Arief furchan dkk, 1992. Qualitative research for education an introduction to theory and methods, Surabaya: Usaha nasional.

Sudjana, (2005)., Metode Statistika.

Penerbit Tarsito Bandung

Sunanik, 2013. Strengthening creative and innovative economy based on Resourceddaya Besuki Village In, Besuki Tulungagung J-Adimas Subdistrict (Journal of Community Service) Volume 1, Number 1, July 2013: 20-27

World Health Organization. Naming the coronavirus disease (COVID-19) and the virus that causes it [internet]. Geneva: World Health Organization; 2020 [cited 2020 March 29]. Available from: http://www.who.int/emergencies/diseases/novel-coronavirus-2019/technicalguidance/naming-the-coronavirus-disease-(covid-2019)-and-the-virus-that causes-it.

(https://republika.co.id/berita/qdgt5p383/tiga-dampak-besar-pandemi-covid19-bagi-ekonomi-ri) 